\title{
Exploring Innovative Marketing Opportunities for Halal Entrepreneurs in Hospitality and Tourism Industry
}

\author{
Mohamed Battour ${ }^{1,}$, Mohamed Salaheldeen ${ }^{2}$ and Khalid Mady ${ }^{3}$ \\ ${ }^{1}$ Faculty of Faculty of leadership and management, Universiti Sains Islam Malaysia (USIM), \\ Malaysia and, University of Sharjah, Sharjah, UAE. \\ ${ }^{2}$ Faculty of Economics and Muamalat Administration, Universiti Sains Islam Malaysia and, Faculty \\ of Commerce, Menoufia University, Egypt. \\ ${ }^{3}$ Faculty of Management \& Economics and social development, Universiti Malaysia Terengganu, \\ Malaysia.
}

\begin{abstract}
Innovation is essential for long-term competitiveness of firms. The lack of innovation can reduce the competitiveness of firms in the hospitality and tourism industry. Therefore, Halal entrepreneurs in the Halal travel market must prepare for a future led by innovation and technology and to build scalable, digitally enabled business models. There are many innovative opportunities that can be translated into Halal tourism product/services for Muslim and non-Muslim travellers. Some aspects of Halal travel may also satisfy the demands of the non-Muslim market. The paper discusses seven innovative opportunities that could be exploited by Halal entrepreneurs in the hospitality and tourism market. The findings are useful for entrepreneurs to develop Halal products and services for Muslim and non-Muslim travellers.
\end{abstract}

\section{Introduction}

Innovation is essential for long-term competitiveness. Competitiveness in the hospitality and tourism industry may be inhibited by the lack of innovation. Entrepreneurs in the Halal industry should exploit numerous opportunities to enhance their competitiveness. They should explore various opportunities and translate them into Halal tourism product/services that cater to both Muslim and non-Muslim travellers (M. Battour, 2019; M. Battour, Hakimian, Ismail, \& Boğan, 2018; M. Battour, Rahman, \& Rana, 2019; M. M. Battour, Battor, \& Ismail, 2012). Some aspects of Halal travel are not exclusively for Muslims; they may also satisfy the demands of non-Muslim travellers. Halal travel/tourism and Muslimfriendly travel are growing areas of Halal entrepreneurship (M. Battour et al., 2019; M. Battour, Salaheldeen, \& Mady, 2021; M. M. Battour, Ismail, \& Battor, 2010; M. M. K. Battour, 2011; Salaheldeen, Battour, \& Nazri, 2019). Entrepreneurs in the Halal travel industry must prepare for a future led by innovation and technology and to build scalable,

\footnotetext{
* Corresponding author: mbattour@usim.edu.my
} 
digitally enabled business models. These business models should also consider sustainability due to its increasing import in the hospitality and tourism industry. Technology, innovation, and travel efficiency will continue to play key roles in managing sustainability-related costs (Mastercard-CrescentRating, 2020).

The entrepreneurship literature has extensively covered innovation and opportunity exploitation (Guo, Tang, Su, \& Katz, 2017; Kuckertz, Kollmann, Krell, \& Stöckmann, 2017; Miocevic \& Morgan, 2018; Salaheldeen, 2015, 2017), but research on both variables in the hospitality and tourism industry is still limited (Lee, Hallak, \& Sardeshmukh, 2016; Power, Di Domenico, \& Miller, 2017). Innovation is a key concept not only in business and entrepreneurial research but also in the broader social sciences. Yet it has received little attention in empirical research despite its policy and academic importance. There is little research on the role of innovation in tourism and the contribution of tourism-related human mobility to regional, firm, and product innovation (Hall \& Williams, 2019; Noureldeen, Salaheldeen, \& Battour, 2022). Fu, Okumus, Wu, and Köseoglu (2019) claim that entrepreneurship research in hospitality and tourism is very limited, especially in terms of theoretical development. Similarly, there is also limited entrepreneurship research on Halal travel that satisfies Muslim travellers as a segment with unique needs and behaviours. The recent years has seen the emergence of "Halal Travel 1.0", where travel destinations and businesses began embracing the Halal travel segment and catering to the needs of Muslim travellers. The next phase, Halal Travel 2.0, will be enabled by technologies such as Artificial Intelligence (AI), Augmented Reality (AR), and Virtual Reality (VR). This paper explains some innovative business opportunities in the Halal travel industry that may be exploited by Halal entrepreneurs.

\section{Halal Entrepreneurship}

An Islamic-based economic framework should consider different social, spatial, and community forms, in addition to the various codes, norms, and symbols that define society more generally (Boubekeur, 2016; Karia \& Asaari, 2016; Soltanian, Zailani, Iranmanesh, \& Aziz, 2016; Tok \& Kaminski, 2018). The Halal business model is a strategic model derived from Islamic teachings, particularly the Quran and Hadith, that can ensure sustainable and accountable business practices of the firm. Halal was a strictly religious concept, but it is now used as a branding platform for entrepreneurs to grow and market their products (M. Battour, Salaheldeen, Mady, \& Elsotouhy, 2021; Salindal, 2018). The Halal global market and food industry are rapidly emerging globally. Halal entrepreneurship is an entrepreneurial process for the innovative exploitation of opportunities for the purpose of generating sustainable economic returns while realising an equitable society (Khalek, 2018). The concept is referred to as "Halal entrepreneurship" (Ramadani, Dana, Ratten, \& Tahiri, 2015) or "Halal-minded entrepreneurship" (Soltanian et al., 2016).

Malaysia is currently witnessing rapid growth of Halal entrepreneurship. Accordingly, in 2015, it was ranked first in the global Halal Food Indicators, ahead of the United Arab Emirates and Australia (Zakaria \& Kaushal, 2017). Halal entrepreneurship emerged with Halal food before extending to other areas, for instance cosmetics, pharmaceuticals, personal care, banking, finance, tourism, hospitality, and logistics (Khalek, 2018). From an Islamic perspective, entrepreneurship is a complex and contested concept that is founded on three interlinking pillars: entrepreneurial, socio-economic/ethical, and religio-spiritual (Ramadani et al., 2015). Halal entrepreneurship differs from ethical entrepreneurship because it has specified practices that are based on religious sources and a meta-physical objective (Gümüsay, 2015).

Entrepreneurship from the Islamic perspective affects the micro- and macro-levels of analysis in multifaceted ways by shaping the individual, organisation, and institution, e.g., 
market and state (Gümüsay, 2015; Khalek, 2018; Tok \& Kaminski, 2018). The Islamic market is growing along with the increasing number of Muslim entrepreneurs, businesspeople, and patrons whose identity centres around Islam; they partake in Islamic businesses for religious and social empowerment (Boubekeur, 2016). Although the entrepreneur is a natural person, entrepreneurship cannot be entirely divorced from the general social settings within which any business is situated.

Salindal (2018) highlights the positive effect of Halal certification on the innovative performance of Halal-certified food companies. Thai entrepreneurs perceive Halal certification to positively contribute towards sales and profit growth, export opportunity, product reliability and quality, Muslim consumers' trust, and local and international market expansion (Sriviboone \& Komolsevin, 2018). The increasing number of Muslim travellers to non-Muslim countries indicates the urgency to examine the capacity and willingness of such destinations to fully cater to the needs of Muslims. For instance, Italy is gradually offering Halal products, accommodation, and worship facilities.

\section{Innovative opportunities}

Innovation is essential to support sustainable growth. O'dwyer, Gilmore, and Carson (2009) define innovation as "the process of taking new ideas effectively and profitably through to satisfied customers". The inability or failure to innovate may cause firms to be less competitive (Hsieh \& Kelley, 2016). Empirical evidence shows the importance of innovative opportunities in creating competitive advantage for new ventures during market entry (Battor \& Battour, 2013; Chatzoglou \& Chatzoudes, 2018; Markides \& Sosa, 2013). A critical phase in entrepreneurship is exploiting the opportunity to create new venture. New ventures that exploit innovative opportunities are more likely to enter the market successfully (Battor \& Battor, 2010; M. Battour, 2018, 2019; M. Battour, Battor, \& Bhatti, 2013).

Innovative opportunity is "the possibility to realise a potential economic value inherent in a new combination of resources and market needs, emerging from changes in the scientific or technological knowledge base, customer preferences, or the interrelationships between economic actors" (Holmén, Magnusson, \& McKelvey, 2007). Halal entrepreneurs must exploit innovative opportunities in the hospitality and tourism industry, introducing new products and services with new value propositions that satisfies the needs of Muslim travellers. Those new products and services should equally target Muslim and non-Muslim customers. The mission of Halal entrepreneurs is to seek profit, founding their strategies on current and future market trends and customer demands. At the same time, Halal entrepreneurs should run their ventures according to Shariah (Islamic law).

\section{Potential areas for Halal entrepreneurs}

\subsection{Gen Alpha as a potential customer}

Generation Alpha (Gen Alpha) is the first generation to be born in the twenty-first century. They are mostly children of Millennials and sometimes Generations X and Z. Generation Alpha are natural users of smartphones and tablets. They were born with iPhones, iPads, and applications, and so they cannot imagine life without them. They are not afraid to learn and use technology. The unique characteristics of Gen Alpha will influence the travel behaviours of families. Therefore, Halal entrepreneurs must prepare to meet the future needs of Gen Alpha travellers. Family travel decision in the near future will be decided by Gen Alpha (M. Battour, Ismail, Battor, \& Awais, 2017; Mastercard-CrescentRating, 2020). 
To cater to Muslim families with Gen Alpha children, Halal entrepreneurs can offer tailored edutainment and activities during various travel touchpoints, as well as special family discounts and packages. They can also design travel discovery books and travel packages that are packed with adventure to target Gen Alpha.

\subsection{Digital platform Era}

Digital platforms are a ubiquitous marketplace in today's world. Entrepreneurs can easily offer their products/services on such platforms, and customers can easily find products/services that suit their needs. For Halal hospitality and tourism, Halal entrepreneurs can develop a new digital platform or application that offers personalised products and services to Muslim travellers. The platform or application should be extremely user-friendly so that the customers can share everything. Potential customers typically use mobile apps to find information about products/services. New Halal tourism ventures should take full advantage of mobile optimised messaging as a potential innovative opportunity. They should also make the most of real-time engagement afforded by social media to reach young Muslims. The new ventures should produce contents that can engage these digital natives.

Halal entrepreneurs can also develop a digital platform for Umrah and Hajj. Umrah service providers must move beyond providing basic education and logistics support to truly delivering exceptional service experiences for consumers. They can differentiate by offering data-powered services. In multiple points throughout the Umrah travel, they can provide personalised and or interactive contents to Umrah pilgrims. These contents may cover the customs, rituals, and Umrah locations, delivered through 360-degree live video streams and augmented tours via smartphones. Additionally, the providers and pilgrims can share their experiences during Umrah using highspeed internet connection.

Another interesting innovative opportunity is research and data analytics services for the Halal travel industry. This opportunity should be taken by data analytics firms. Currently, such services are only offered by a Singapore-based company, CrecsentRating. More Halal entrepreneurs should enter the Halal travel market to increase its competitiveness. The research and data analytics services can help Halal travel firms to analyse the behaviours and needs of Muslim travellers. A Halal booking platform is also necessary, as the providers of Halal booking services are currently limited in quantity, e.g., Halalbooking and Halal Trip.

\subsection{Blockchain-based Cryptocurrency}

Blockchain-based cryptocurrency is a virtual currency used as an internet-based medium of exchange and a popular asset for hedging and speculation purposes. According to Ayedh et al. (2020), compatibility, awareness, and facilitating conditions have increased the interest of Muslim investors in the cryptocurrency market. Halal entrepreneurs may develop cryptocurrency-based payment services for Muslim travellers for its numerous benefits, including decentralised solutions, trust, and transparency (Abboushi, 2017; Antonopoulos, 2014; Ryan, 2017). By developing new financial technology (fintech) to support digital transactions, Halal entrepreneurs can offer new value-added services to Muslim travellers. Halal entrepreneurs may also explore alternative financing and transaction services for Muslim-friendly trips (M. Battour \& Ismail, 2014; M. Battour, Ismail, \& Battor, 2011; Mastercard-CrescentRating, 2020). Fintech will continue to contribute to the innovation of payment solutions globally. Halal entrepreneurs must explore and exploit innovative opportunities in this area, for instance by introducing e-wallets and mobile payment services, which are becoming prevalent among Muslim travellers. 


\subsection{Sustainable Products and services}

Sustainability is an increasingly important determinant of business and consumer choices in the tourism industry. The United Nations and the media have raised awareness on how tourism activities have contributed to environmental issues, most prominently climate and culture. Plastic waste and climate footprint are significant ecological concerns. The wellbeing of all stakeholders in the tourism value chain has also emerged as an important issue. Future travellers, especially younger ones, will reward destinations and companies that can provide quality services while being eco-friendly and culturally respectful. Travellers will be willing to pay a premium for a travel experience that does not compromise the environment and local culture. Muslims as responsible citizens are mindful of the positive impact of sustainable tourism. Therefore, Halal entrepreneurs should exploit sustainable tourism as an innovative opportunity. They can establish new ventures that offer sustainable Halal tourism.

\subsection{Muslim female-friendly services}

According to the Mastercard-CrescentRating Report (MWIT) (2020), around 45 percent of Muslim travellers are women. They are typically young, educated, and have moderate to high purchasing power. Halal entrepreneurs can introduce new products and services to meet the unique needs of Muslim women travellers. In turn, such products and services can encourage more Muslim women to travel. The MWIT Report also states that 28 percent of Muslim women usually travel alone, while the remainder with their families. Regardless of their travel companion, Muslim women are able to plan their trip, indicating that they are mindful decision makers. Thus, Halal entrepreneurs should consider the needs of Muslim women travellers as a potential segment and identify and create service touchpoints to engage them.

\subsection{Culinary tourism}

Halal food is increasingly available in many destinations to cater to Muslim travellers. Tourism service providers and destination operators should introduce Muslim-friendly culinary options. The culinary curiosity of Muslim travellers is increasing, thus food companies are introducing more creative and unique Halal items. This can be seen in many well-known food brands that have adopted Halal food manufacturing. While culinary tourism is becoming more popular among Muslim travellers, their options are often limited because they may only consume Halal food. Like any other travellers, Muslim travellers are keen to try the local cuisines of the host communities or participate in a cooking class, a food tour or a festival to learn and immerse themselves in the local culture. To attract Muslim tourists, many Asian countries have begun catering to their needs. Japan, South Korea, Hong Kong, and Taiwan are some destinations that have led the way for Halal culinary tourism. Therefore, Halal entrepreneurs can exploit innovative opportunities in the food and beverage sector by developing halal culinary products and services.

\subsection{Three-dimensional printing}

The adoption of 3D printing in the manufacturing sector is considerably growing (Rong, Patton, \& Chen, 2018). 3D printing begins by designing a prototype of an object using a software. The 3D printer then manufactures the design by printing several layers of materials until the object is completely created. Metals, plastics, and aluminium are common materials used in 3D printing (Arbabian \& Wagner, 2020). An important 
advantage of $3 \mathrm{D}$ printing is highly customisable products; the customer can modify the product with little to no additional costs (Kwak, Kim, \& Park, 2018). This has led to the prevalent use of 3D printing in various industrial segments, for example equipment, architecture, automotive, medical, education, and consumer products. However, 3D printing as an innovative opportunity has not been fully exploited in the hospitality and tourism industry. Halal entrepreneurs can use 3D printing to manufacture artificial food (food models) (Zsarnoczky, 2018) and personalised souvenirs (Anastasiadou \& Vettese, 2019).

\section{Conclusion and implications}

This paper has discussed how Halal entrepreneurs can explore and exploit innovative opportunities in the hospitality and tourism industry. By identifying these opportunities, they can create new ventures and or tourism product/services that can satisfy the needs of Muslim and non-Muslim travellers. In general, Halal entrepreneurship is an entrepreneurial process for the innovative exploitation of opportunities for the purpose of generating sustainable economic returns while realising an equitable society. Halal entrepreneurship ventures must be run according to Shariah (Islamic law). The paper has also argued the importance of identifying and exploiting innovation opportunities based on current and future market trends and customer demands. It has presented some possible innovative opportunities for Halal entrepreneurs in the hospitality and tourism industry. Halal entrepreneurs can target Gen Alpha by offering tailored edutainment and activities during various travel touchpoints. They can develop new digital platforms to provide personalised Halal travel packages, Halal travel booking, and analytics services. New payment services for Muslim travellers can be developed using blockchain-based cryptocurrency. To attract conscious Muslim and non-Muslim travellers, Halal entrepreneurs should design and offer sustainable tourism products and services. They should also consider the needs of Muslim female travellers as a potential market segment. Introducing Halal culinary products and services is a possible innovative opportunity in the food and beverage sector. Finally, Halal entrepreneurs can use 3D printing for several purposes, such as creating personalised and customised souvenirs.

This conceptual paper fills the gap in hospitality and tourism entrepreneurship research, which hitherto has been fairly limited. The practical contributions of this paper are the identified innovative opportunities which Halal entrepreneurs could exploit to start new ventures. Future research may develop a theorical framework related to Halal entrepreneurs and innovative opportunities in the hospitality and tourism industry.

\section{References}

Abboushi, S. (2017). Global Virtual Currency-Brief Overview. Journal of Applied Business and Economics, 19(6).

Anastasiadou, C., \& Vettese, S. (2019). "From souvenirs to 3D printed souvenirs". Exploring the capabilities of additive manufacturing technologies in (re)-framing tourist souvenirs. Tourism Management, 71, 428-442.

Antonopoulos, A. M. (2014). Mastering Bitcoin: unlocking digital cryptocurrencies: " O'Reilly Media, Inc.".

Arbabian, M. E., \& Wagner, M. R. (2020). The impact of 3D printing on manufacturerretailer supply chains. European Journal of Operational Research.

Ayedh, A., Echchabi, A., Battour, M., \& Omar, M. (2020). Malaysian Muslim Investors' Behaviour Towards the Blockchain-based Bitcoin Cryptocurrency market. Journal of Islamic Marketing, forthcoming 
Battor, M., \& Battor, M. (2010). The impact of customer relationship management capability on innovation and performance advantages: testing a mediated model. Journal of Marketing Management, 26(9-10), 842-857.

Battor, M., \& Battour, M. (2013). Can organizational learning foster customer relationships? Implications for performance. The Learning Organization, 20(4/5), 279-290.

Battour, M. (2018). Muslim Travel Behavior in Halal Tourism. In Mobilities, tourism and travel behavior-contexts and boundaries: InTech.

Battour, M. (2019). Halal Tourism: achieving Muslim tourists' satisfaction and loyalty.

Battour, M., Battor, M., \& Bhatti, M. A. (2013). Islamic Attributes of Destination: Construct Development and Measurement Validation, and Their Impact on Tourist Satisfaction. International Journal of tourism research, 16 (6), 556-564.

Battour, M., Hakimian, F., Ismail, M., \& Boğan, E. (2018). The perception of non-Muslim tourists towards halal tourism. Journal of Islamic Marketing.

Battour, M., \& Ismail, M. N. (2014). The Role of Destination Attributes in Islamic Tourism. SHS Web of Conferences, 12, 01077. Retrieved from http://dx.doi.org/10.1051/shsconf/20141201077

Battour, M., Ismail, M. N., \& Battor, M. (2011). The impact of destination attributes on Muslim tourist's choice. International Journal of Tourism Research, 13(6), 527540.

Battour, M., Ismail, M. N., Battor, M., \& Awais, M. (2017). Islamic Tourism: An Empirical Examination of Travel Motivation and Satisfaction in Malaysia. Current Issues in Tourism, 20(1), 50-67. doi:10.1080/13683500.2014.965665

Battour, M., Rahman, M. K., \& Rana, M. S. (2019). The impact of PHTPS on trip quality, trip value, satisfaction and word of mouth. Journal of Islamic Marketing.

Battour, M., Salaheldeen, M., \& Mady, K. (2021). Halal tourism: exploring innovative marketing opportunities for entrepreneurs. Journal of Islamic Marketing(ahead-ofprint). doi:10.1108/JIMA-06-2020-0191

Battour, M., Salaheldeen, M., Mady, K., \& Elsotouhy, M. (2021). Halal Tourism: What Is Next For Sustainability? Journal of Islamic Tourism 1(Inaugural Issue ), 80-91. Retrieved from http://jistour.org/en-us/makele/halal-tourism--what-is-next-forsustainability $/ 37 / \mathrm{pdf}$

Battour, M. M., Battor, M. M., \& Ismail, M. (2012). The mediating role of tourist satisfaction: A study of Muslim tourists in Malaysia. Journal of Travel \& Tourism Marketing, 29(3), 279-297.

Battour, M. M., Ismail, M. N., \& Battor, M. (2010). Toward a halal tourism market. Tourism Analysis, 15(4), 461-470.

Battour, M. M. K. (2011). The impact of Islamic attributes of destination on tourists' motivation, satisfaction and destination loyalty. University of Malaya,

Boubekeur, A. (2016). Islamic business and Muslim Entrepreneurs networks in Europe: performing transnational modernity and overcoming marginalization. Contemporary Islam, 10(3), 421-432.

Chatzoglou, P., \& Chatzoudes, D. (2018). The role of innovation in building competitive advantages: an empirical investigation. European Journal of Innovation Management.

Fu, H., Okumus, F., Wu, K., \& Köseoglu, M. A. (2019). The entrepreneurship research in hospitality and tourism. International Journal of Hospitality Management, 78, 112.

Gümüsay, A. A. (2015). Entrepreneurship from an Islamic perspective. Journal of Business Ethics, 130(1), 199-208. 
Guo, H., Tang, J., Su, Z., \& Katz, J. A. (2017). Opportunity recognition and SME performance: The mediating effect of business model innovation. R\&D Management, 47(3), 431-442.

Hall, M. C., \& Williams, A. (2019). Tourism and innovation: Routledge.

Holmén, M., Magnusson, M., \& McKelvey, M. (2007). What are innovative opportunities? Industry and innovation, 14(1), 27-45.

Hsieh, R. M., \& Kelley, D. J. (2016). The role of cognition and information access in the recognition of innovative opportunities. Journal of Small Business Management, 54(sup1), 297-311.

Karia, N., \& Asaari, M. H. A. H. (2016). Halal business and sustainability: strategies, resources and capabilities of halal third-party logistics (3PLs). Progress in Industrial Ecology, an International Journal, 10(2-3), 286-300.

Khalek, A. A. (2018). Entrepreneurship and the Halal Wave in Malaysia. In Global Entrepreneurship and New Venture Creation in the Sharing Economy (pp. 191205): IGI Global.

Kuckertz, A., Kollmann, T., Krell, P., \& Stöckmann, C. (2017). Understanding, differentiating, and measuring opportunity recognition and opportunity exploitation. International Journal of Entrepreneurial Behavior \& Research.

Lee, C., Hallak, R., \& Sardeshmukh, S. R. (2016). Innovation, entrepreneurship, and restaurant performance: A higher-order structural model. Tourism Management, 53, 215-228.

Markides, C., \& Sosa, L. (2013). Pioneering and first mover advantages: the importance of business models. Long range planning, 46(4-5), 325-334.

Mastercard-CrescentRating. (2020). Halal Travel Frontier 2020. Retrieved from https://www.crescentrating.com/reports/halal-travel-frontier-2020.html

Miocevic, D., \& Morgan, R. E. (2018). Operational capabilities and entrepreneurial opportunities in emerging market firms. International Marketing Review.

Noureldeen, A., Salaheldeen, M., \& Battour, M. (2022). Critical Success Factors for ERP Implementation: A Study on Mobile Telecommunication Companies in Egypt. In M. Al-Emran, M. A. Al-Sharafi, M. N. Al-Kabi, \& K. Shaalan (Eds.), Proceedings of International Conference on Emerging Technologies and Intelligent Systems. ICETIS 2021. Lecture Notes in Networks and Systems (Vol. 299, pp. 691-701). Cham: Springer

O'dwyer, M., Gilmore, A., \& Carson, D. (2009). Innovative marketing in SMEs. European Journal of Marketing.

Power, S., Di Domenico, M., \& Miller, G. (2017). The nature of ethical entrepreneurship in tourism. Annals of Tourism Research, 65, 36-48. doi:https://doi.org/10.1016/j.annals.2017.05.001

Ramadani, V., Dana, L.-P., Ratten, V., \& Tahiri, S. (2015). The context of Islamic entrepreneurship and business: Concept, principles and perspectives. International Journal of Business and Globalisation, 15(3), 244-261.

Rong, K., Patton, D., \& Chen, W. (2018). Business models dynamics and business ecosystems in the emerging 3D printing industry. Technological Forecasting and Social Change, 134, 234-245.

Ryan, P. (2017). Smart contract relations in e-commerce: Legal implications of exchanges conducted on the blockchain. Technology Innovation Management Review.

Salaheldeen, M. (2015). Management Control Systems as a Package: an application to Science \& Technology Parks: UPTEC Case Study. Paper presented at the 8th Conference On Performance Measurement And Management Control, Nice, France. 
Salaheldeen, M. (2017). Artificial Intelligence in Business Research: trends and future. Paper presented at the Emerging Issues and Challenges in Management Conference, Faculty of Commerce, Menoufia University, Egypt.

Salaheldeen, M., Battour, M., \& Nazri, M. A. (2019). Halal entrepreneurship and its role in sustainable development goals 2030 (SDGs). Paper presented at the International Conference on Dakwah and Islamic Management (IC-DAIM 2019) Malaysia.

Salindal, N. A. (2018). Halal certification compliance and its effects on companies' innovative and market performance. Journal of Islamic Marketing, 0(0), null. doi:10.1108/jima-04-2018-0080

Soltanian, M., Zailani, S., Iranmanesh, M., \& Aziz, A. A. (2016). Motivations of SME entrepreneurs to become halalpreneurs. Journal of Science and Technology Policy Management, 7(2), 173-189. doi:doi:10.1108/JSTPM-07-2015-0023

Sriviboone, S., \& Komolsevin, R. (2018). Perception of Thai Entrepreneurs toward Halal Certification. BU Academic Review, 17(1), 33-47.

Tok, M. E., \& Kaminski, J. (2018). Islam, entrepreneurship, and embeddedness.

Zakaria, N., \& Kaushal, L. A. (2017). Global Entrepreneurship and New Venture Creation in the Sharing Economy: IGI global.

Zsarnoczky, M. (2018). The digital future of the tourism \& hospitality industry. Boston Hospitality Review, 6. 